\title{
Analisis Penyelenggaraan Pemilihan Kepala Daerah Dimasa Pandemi Covid-19 Berdasarkan Undang-Undang Nomor 6 Tahun 2020 Tentang Penetapan Peraturan Pemerintah Pengganti Undang-Undang Nomor 2 Tahun 2020 Tentang Perubahan Ketiga Atas Undang-Undang Nomor 1 Tahun 2015 Tentang Pemilihan Gubernur, Bupati, dan Walikota (Studi di KPU Kota Bandar Lampung)
}

\author{
Lintje Anna Marpaung ${ }^{1}$, Baharudin ${ }^{2 *}$, Anggalana ${ }^{3}$, Muhammad Affandi ${ }^{4}$ \\ ${ }_{1,2,3,4}$ Fakultas Hukum Universitas Bandar Lampung \\ Jln. ZA. Pagar Alam No. 26 Labuhan Ratu Bandar Lampung Provinsi Lampung \\ *Correspondence email: baharudin@ubl.ac.id, 17211038@student.ubl.ac.id
}

\begin{abstract}
Abstrak. Ajang pemilihan Kepala Daerah yang di harapkan akan dilaksanakan pada Bulan September terpaksa harus ditunda sampai Bulan Desember tentu saja pengunduran jadwal tersebut bukan tanpa alasan, maraknya penyebaran wabah virus pandemi Covid-19 menjadi suatu halangan tersendiri oleh Komisi Pemilihan Umum untuk bisa menyelenggarakan Pemilihan Kepala Daerah sebab keselamatan masyarakat ialah hal utama yang harus dipikirkan oleh Komisi Pemilihan Umum ini disebabkan karena virus ini dapat menyerang siapa saja dan dampak terburuk ialah meninggal nya seseorang, oleh karena itu Komisi Pemilihan Umum membuat suatu metode terbaru terkait pemilihan Kepala Daerah yaitu dengan menerapkan protokol kesehatan di tempat pemungutan suara yang akan diterapkan kepada seluruh petugas hingga masyarakat yang sudah memiliki hak suara berdasarkan undang-undang mekanisme ini akan diterapkan kepada pemilih dari yang bersuhu tubuh normal, bersuhu tubuh 37,3 derajat celsius hingga kepada pemilih yang terpapar Covid-19, selain mekanisme yang lebih rumit dampak lain yang dihasilkan dari Covid-19 pemilihan yang lebih rumit dari sebelumnya dan biaya penyelenggaraan yang lebih mahal karena harus menggunakan alat protokol kesehatan yang harus diberikan kepada seluruh petugas dan masyarakat.
\end{abstract}

Kata kunci: Mekanisme; Dampak; Covid-19

\begin{abstract}
The Regional Head election event which is expected to be held in September has to be postponed until December of course the postponement of the schedule is not without reason, the widespread spread of the Covid-19 pandemic virus outbreak is a separate obstacle for the General Election Commission to be able to hold Regional Head Elections because Public safety is the main thing that must be considered by the General Election Commission because this virus can attack anyone and the worst impact is the death of a person, therefore the General Election Commission made a new method related to regional head elections, namely by implementing health protocols in place. voting which will be applied to all officers to people who already have voting rights under the law this mechanism will be applied to voters from normal body temperature, body temperature 37.3 degrees Celsius to voters exposed to Covid-19 In addition to a more complicated mechanism, the impact resulting from Covid-19 is a more complicated election than before and the cost of organizing it is more expensive because it has to use a health protocol tool that must be given to all officers and the public.
\end{abstract}

Keywords: Mechanism; Impact; Covid-19

\section{PENDAHULUAN}

Negara Indonesia adalah Negara Kesatuan Republik Indonesia. ${ }^{1}$ hal ini berdasarkan Pasal 1 ayat (1) jo Pasal 37 ayat (5) Undang-Undang Dasar Negara Republik Indonesia 1945, yang menjunjung terhadap kedaulatan rakyat hal ini juga sesuai dengan isi ketentuan yang ada Pada alinea ke IV Undang-Undang Dasar Negara Republik Indonesia 1945 yang menyatakan bahwa berkedaulatan Rakyat dengan berdasarkan kepada Pancasila". dan kemudian kedaulatan tersebut dipertegas kembali sesuai yang termaktub pada Pasal 1 ayat (2) Undang-Undang Dasar Negara Republik Indonesia 1945 yang menyatakan bahwa, "Kedaulatan berada di tangan rakyat dan dilaksanakan menurut UndangUndang Dasar. prinsip kedaulatan rakyat memiliki mekanisme dalam pelaksanaan Pemilihan Pemimpin salah satu nya yaitu melalui Pemilihan Umum Kepala Daerah atau yang biasa disebut Pemilukada, Pemilihan Umum Kepala Daerah secara langsung di maknakan sebagai bentuk Pemilihan yang dilakukan oleh rakyat secara langsung, dan suara mayoritas terbanyak akan menjadi acuan pemenang dalam Pemilukada tersebut pemilihan yang diadakan seluruh Daerah. $^{2}$

\footnotetext{
${ }^{1}$ Lintje Anna Marpaung, Revitalisasi Hukum Otonomi Daerah Prospektif Kepentingan Daerah, Aura, Bandar Lampung,
} 2016, hlm 1 .

${ }^{2}$ Hendra Budiman, Pilkada Tidak Langsung dan Demokrasi Palsu. Pustaka Yustisia, Yogyakarta, 2015, hlm 161. 
Lintje Anna Marpaung, Baharudin, Anggalana dan Muhammad Affandi, Analisis Penyelenggaraan Pemilihan Kepala Daerah Dimasa Pandemi Covid-19 Berdasarkan Undang-Undang Nomor 6 Tahun 2020 Tentang Penetapan Peraturan Pemerintah Pengganti Undang-Undang Nomor 2 Tahun 2020 Tentang Perubahan Ketiga Atas Undang-Undang Nomor 1 Tahun 2015 Tentang Pemilihan Gubernur, Bupati, dan Walikota (Studi di KPU Kota Bandar Lampung)

Secara harfiah, Pemilukada sebagai salah satu bentuk terhadap ide dan gagasan yang terbentuk dalam proses demokrasi dengan adanya jaminan kebebasan kepada setiap individu dan kesetaraan pada segala bidang ruang demokrasi yang memiliki arti nilai partisipasi serta menjunjung kedaulatan yang tinggi dan dijalankan oleh setiap masyarakat. $^{3}$

Dalam proses menjalankan sistem demokrasi, adanya beberapa prinsip yang harus dilaksanakan oleh masyarakat sebagai bentuk partisipasi dalam bidang politik, adanya pembagian kekuasaan di antara lembaga negara, pemilihan yang bebas dan jujur, keterbukaan, adanya kebebasan individubagi setiap orang, pengakuan kepada hakhak minoritas, Pemerintahan berdasarkan hukum, kebebasan pers, adanya persetujuan, Pemerintahan berdasarkan kepada konstitusional, perlindungan hak asasi, mekanisme politik, dan adanya pemerintah yang mengutamakan musyawarah mufakat adalah sederet bentuk prinsip yang merupakan ciri-ciri terselenggaranya sebuah demokrasi. ${ }^{4}$

Mengenai Pemilihan Umum Kepala Daerah diatur dalam Pasal 18 ayat (4) Undang-Undang Dasar Negara Republik Indonesia 1945 yang menyatakan bahwa: "Gubemur, Bupati, dan Walikota masing-masing sebagai Kepala Pemerintahan Daerah provinsi, kabupaten, dan kota dipilih secara demokrasi istilah Kepala Daerah dan Wakil Kepala Daerah, Pemilihan biasa disebut sebagai Pemilukada, dalam penyelenggaraan Pemilukada di Indonesia yang akan dilakukan secara serentak meliputi 9 Provinsi, 224 Kabupaten, dan 37 Kota yang akan di laksanakan pada Tanggal 23 September 2020 harus dilakukannya penundaan karena terjadi penyebaran pandemi Covid-19 efek yang dihasilkan kepada seseorang yang di diagnosa terpapar oleh virus korona akan menyerang saluran pernapasan yang bisa menyebabkan sakit seperti sesak napas, demam tinggi, batuk, flu, serta nyeri tenggorokan dan penyebab terburuk ialah terjadinya kematian kepada seseorang.

Akhir-akhir ini penyebaran virus Covid-19 terus meningkat, ini menjadikan Indonesia menjadi salah satu Negara yang terdampak oleh wabah pandemi Covid-19 saat ini saja tercatat 135.123 kasus Covid-19 terhitung sejak diumumkannya kasus pertama, dengan mengingat bahaya nya wabah Covid-19 tersebut, melalui amanat yang tertulis dalam Pasal 12 Undang-Undang Dasar Negara Republik Indonesia 1945 Presiden kemudian menerbitkan Keputusan Presiden Republik Indonesia Nomor 11 Tahun 2020 tentang Penetapan Kedaruratan Kesehatan Masyarakat Corona virus disease 2019 (Covid-19) kebijakan yang sudah disahkan tersebut telah tertuang ke dalam penerapan Pembatasan Sosial Berskala Besar berupa pembatasan-pembatasan yang mulai dilakukan dan imbauan untuk menghindari adanya kegiatan-kegiatan yang melibatkan orang banyak dan dapat menyebabkan penyebaran virus Covid-19 dengan cepat, dengan adanya penundaan agenda ketataNegaraan yang menjadi pertimbangan Pemerintah dalam hal ini ketika terjadi wacana akan diadakannya Pemilukada serentak di 270 Daerah secara bersamaan salah satunya yaitu di Kota Bandar Lampung yang akan mengadakan Pemilihan calon Walikota dan Wakil Walikota harus ada nya Penundaan dengan datang nya wabah Covid-19.

Dampak yang dirasakan langsung oleh pemilih dan penyelenggara diakibatkan karena terjadinya pandemi Covid-19 salah satunya terhadap mekanisme pememilihan secara langsung di TPS yang akan dilakukan oleh pemilih, pengunaan alat protokol kesehatan merupakan hal wajib yang harus digunakan oleh setiap orang yang terlibat langsung dalam pemilihan ini sesuai dengan Peraturan Komisi Pemilihan Umum Nomor 6 Tahun 2020 selain itu dampak lainnya anggaran yang tidak sedikit akan dikeluarkan oleh pemerintah untuk membiayai pengunaan alat protokol kesehartan dan pemilihan yang lebih rumit, tentu semua dilakukan untuk menghindari penyebaran Covid-19 dan tidak mengurangi esensi asas-asas pemilu yang sering disebut luber-jurdil.

\section{METODE}

\section{Metode Pendekatan}

Penelitian ini menggunakan pendekatan yang bersifat yuridis normatif dan empiris

1. Pendekatan yuridis normatif ialah dengan menggunakan perundang-undangan yang terkait dengan Pemilihan Umum Kepala Daerah

2. Pendekatan empiris yaitu dilakukan dengan melihat secara langsug terkait objek penelitian dengan cara observasi dan wawancara

3. Sumber Data terdiri dari bahan

a. Bahan Hukum Primier

1) UUD NRI 1945 hasil Amandemen

${ }^{3}$ Farahdiba Rahma Bactiar. 2014. Pemilu Indonesia: Kiblat Negara Demokrasi dari Berbagai Representasi. dimuat pada Jurnal Politik Profetik, Vol. 3, No. 1, (2014), hlm 2.

${ }^{4}$ Janpatar Simamora. 2011. Eksistensi Pemilukada Dalam Rangka Mewujudkan Pemerintahan Daerah yang Demokratis. Volume 23, Nomor 1, Februari 2011, hlm 225. 
Lintje Anna Marpaung, Baharudin, Anggalana dan Muhammad Affandi, Analisis Penyelenggaraan Pemilihan Kepala Daerah Dimasa Pandemi Covid-19 Berdasarkan Undang-Undang Nomor 6 Tahun 2020 Tentang Penetapan Peraturan Pemerintah Pengganti Undang-Undang Nomor 2 Tahun 2020 Tentang Perubahan Ketiga Atas Undang-Undang Nomor 1 Tahun 2015 Tentang Pemilihan Gubernur, Bupati, dan Walikota (Studi di KPU Kota Bandar Lampung)

2) Undang-Undang Nomor 23 Tahun 2014 jo Undang-Undang Nomor 9 Tahun 2015 tentang Pemerintahan Daerah

3) Undang-Undang Nomor 7 Tahun 2017 tentang Pemilihan Umum

4) Undang-Undang Nomor 6 Tahun 2020 Tentang Penetapan Peraturan Pemerintah Pengganti Undang-Undang Nomor 2 Tahun 2020 Tentang Perubahan Ketiga Atas Undang-Undang Nomor 1 Tahun 2015 Tentang Penetapan Peraturan Pemerintah Pengganti Undang-Undang Nomor 1 Tahun 2014 Tentang Pemilihan Gubernur, Bupati, Dan Walikota Menjadi Undang-Undang

5) Peraturan Pemerintah Nomor 21 Tahun 2020 Tentang Pembatasan Sosial Berskala Besar Dalam Rangka Percepatan Penanganan Corona Virus Disease 2019 (Covid-19)

6) Keputusan Presiden Republik Indonesia Nomor 11 Tahun 2020 tentang penetapan kedaruratan kesehatan masyarakat Corona Virus Disease 2019 (Covid-19)

7) Peraturan Walikota Bandar Lampung Nomor 25 Tahun 2020 Tentang Penerapan Disiplin dan Penegakan Hukum Protocol Kesehatan Dalam Upaya Pencegahan dan Pengendalian Corona virus disease 2019

8) Peraturan Komisi Pemilihan Umum Nomor 6 Tahun 2020 tentang pelaksanaan Pemilihan Gubernur dan Wakil Gubernur, Bupati dan Wakil Bupati, dan/atau Wali Kota dan Wakil Wali Kota serentak lanjutan dalam kondisi bencana nonalam corona virus disease 2019 (Covid-19)

b. Bahan hukum sekunder

Bahan hukum sekunder dalam penelitian ini bersumber dari bahan bahan hukum yang dapat membatu menganalisis permasalahan dari berbagai buku hukum, arsip, jurnal dan dokumen.

c. Bahan hukum tertier

Bahan hukum teriser dalam penelitian ini bersumber dari Kamus Hukum, Kamus Bahasa Indonesia, Kamus Bahasa Inggris, dan sumber internet.

\section{Prosedur Pengumpulan dan Pengelolan Data}

1. Data Sekunder

Pengumpulan data dengan melakukan serangkaian kegiatan membaca, menelaah, dan menguntip dari bahan kepustakaan serta melakukan pengkajian terhadap ketentuan Peraturan Perundang-undangan yang berrkaitan dengan pokok bahasan.

2. Data Primer

a. Pengamatan (Observation) yaitu melakukan pengamatan dan pencataan terhadap data dan fakta yang ada di lokasi penilitian di kantor KPU Kota Bandar Lampung.

b. Wawancara (Interview), yaitu menggunakan pedoman wawancara yang telah di persiapkan sebelumnya. wawancara dilakukan terhadap narasumber yakni:

Ketua KPU Kota Bandar Lampung : 1 Orang

\section{Analisis Data}

Analisis data yang digunakan ialah analisis yuridis kualitatif, yaitu dengan memberikan pengertian terhadap data yang diperoleh dilapangan yang kemudian disusun, diuraikan dalam bentuk kalimat

\section{HASIL DAN PEMBAHASAN}

Bagaimana mekanisme pemilihan kepala daerah di Kota Bandar Lampung pada masa Pandemi Covid-19

Pada proses penyelenggaraan Pemilihan Umum Kepala Daerah Tahun 2020 ini, mekanisme atau tata cara pelaksanaan nya akan sangat berbeda jika dibandingkan dengan penyelenggaraan Pemilihan Umum Kepala Daerah pada Tahun sebelumnya terjadinya wabah pandemi Covid-19 ini, di mana pada Tahun sebelumnya panitia penyelenggara maupun masyarakat yang akan menyalurkan hak pilihnya bebas dan aktif dalam melaksanakan pemilihan umum, namun pada Tahun ini mekanisme Pemilihan akan diselenggarakan dengan lebih mengedepankan terhadap protokol kesehatan yang sudah ditentukan sebagai upaya dalam pencegahan dan pengendalian wabah virus Covid-19 dengan mempertimbangkan kesehatan dan keselamatan seluruh pihak yang terlibat, pada penyelenggaraan Pemilihan Umum Kepala Daerah ini pelaksanaan protokol kesehatan akan dimulai dari ketua KPU, serta anggota dan sekretariat KPU Provinsi dan KPU Kabupaten/Kota, serta Panitia Pemilihan Kecamatan atau yang disingkat (PPK), dan Panitia Pemungutan Suara atau yang disingkat (PPS) yang akan dites sebelum acara dimulai secara berkala dilakukan rapid test atau Real Time Polymerase Chain Reaction atau yang disingkat (RT-PCR), setelah itu wajib bagi setiap anggota Komisi Pemilihan Umum, Panitia Pemungutan Suara, Panitia Pemilih Kecamatan untuk selalu menggunakan alat pelindung diri seperti halnya berupa masker yang menutupi hidung dan mulut hingga dagu. 
Lintje Anna Marpaung, Baharudin, Anggalana dan Muhammad Affandi, Analisis Penyelenggaraan Pemilihan Kepala Daerah Dimasa Pandemi Covid-19 Berdasarkan Undang-Undang Nomor 6 Tahun 2020 Tentang Penetapan Peraturan Pemerintah Pengganti Undang-Undang Nomor 2 Tahun 2020 Tentang Perubahan Ketiga Atas Undang-Undang Nomor 1 Tahun 2015 Tentang Pemilihan Gubernur, Bupati, dan Walikota (Studi di KPU Kota Bandar Lampung)

Bagi anggota PPS, PPDP dan KPPS diharuskan untuk menggunakan alat pelindung diri berupa masker yang dapat menutupi bagian hidung dan mulut hingga dagu dan diharuskan menggunakan sarung tangan yang hanya dipakai sekali, serta menggunakan pelindung wajah atau (face shield) bagi PPS yang sedang melakukan Yang terkait dukungan Bakal Pasangan Calon perseorangan, verifikasi faktual dan juga bagi anggota PPDP yang sedang melaksanakan pencocokan dan penelitian atau yang disingkat Coklit serta KPPS yang sedang melakukan Pemungutan dan Penghitungan Suara di TPS, selain itu saksi dan pengawas TPS yang hadir wajib mengenakan masker dan sarung tangan sekali pakai dan tidak diharuskan untuk melakukan jabat tangan atau kontak fisik lainnya.

Dalam peraturan Komisi Pemilihan Umum yang baru mengharuskan adanya penyediaan sarana cuci tangan atau hand sanitizer yang cukup, pada tempat-tempat perlengkapan yang akan digunakan sebagai sarana kegiatan dalam penyelenggaraan tahapan Pemilihan yang berupa fasilitas untuk cuci tangan dengan air mengalir dan sabun, harus dilakukan disinfektan atau cairan antiseptik yang berbasis alkohol bagi setiap orang yang terlibat dalam Pemilihan Umum Kepala Daerah tersebut.

Berdasarkan wawancara penulis kepada ketua KPU Kota Bandar Lampung yaitu Bapak Dedy Triyadi ia mengatakan dalam pemilihan Umum Kepala Daerah Tahun ini diharuskan adanya pengurangan pembatasan pemilih yang hadir di setiap TPS dari yang sebelumnya dihadiri 800 peserta kini dikurangi maksimal menjadi 500 sampai 400 peserta pemilih saja dan juga dalam pemilihan akan dibagi jam kehadiran peserta pemilih untuk datang ke TPS yang diatur setiap per-jam untuk sekian pemilih saja yang dipersilakan datang tentu saja pengurangan ini untuk bisa mencegah kerumunan masyarakat yang hadir dan ditakutkan terjadinya penyebaran virus Covid-19, bagi pemilih diharapkan membawa e-ktp dan alat tulis seperti pena, bagi pemilih yang sudah ditetapkan menjadi Daftar Pemilih Tetap atau yang disingkat dengan DPT harus menjalankan mekanisme protokol kesehatan bila ingin melaksanakan pencoblosan suara yang sudah ditetapkan berdasarkan peraturan undang-undang yaitu meliputi :

1. Wajib menggunakan masker bagi setiap orang yang datang dan DPT untuk menghindari dan antisipasi penyebaran virus melalui udara jika bagi pemilih tidak membawa masker maka petugas TPS setempat wajib untuk memberikan masker kepada pemilih yang tidak memakai masker.

2. Setelah menggunakan masker yang dibawa dari rumah atau yang diberikan oleh TPS setempat maka bagi setiap pemilih diwajibkan untuk melakukan cuci tangan yang sudah disiapkan oleh TPS setempat dengan menggunakan Hand Sanitizer.

3. Setelah melakukan cuci tangan pemilih akan dicek suhu tubuh nya dengan menggunakan Thermo Gun sebagai antisipasi penyebaran wabah virus Covid-19 bilamana diketahui bahwa dari seorang pemilih setelah diperiksa memiliki suhu tubuh 37,3 Cellcius maka pemilih tersebut akan diarahkan ke bilik khusus untuk memilih yang sudah disediakan oleh TPS setempat.

4. Setelah diperiksa suhu tubuh bagi para pemilih dan diketahui masih memiliki batas suhu yang wajar maka selanjutnya setiap pemilih akan diberikan berupa sarung tangan plastik yang hanya diperkenakan sekali pakai saja pada proses pencoblosan dibilik suara.

5. Setelah itu pemilih dipersilakan masuk untuk duduk namun dengan penerapan Physical Distancing di antara pemilih yang ditentukan dengan berjarak sekitar 1 meter dari tempat duduk satu dan yang lainnya, pemilih menunggu untuk dipangil oleh petugas TPS, untuk pemilih yang tidak termasuk DPT diwajibkan untuk membawa e-ktp dan memilih dari jam 12:00 sampai jam 13:00 WIB.

6. Setelah itu pemilih akan dipangil oleh petugas untuk dapat memilih dibilik suara yang sudah disediakan.

7. Setelah melakukan pemberian suara maka pemilih diwajibkan untuk membuang sarung tangan plastik yang diberikan oleh petugas TPS ke ditempat yang sudah disediakan oleh panitia setempat.

8. Kemudian pemilih dipersilakan untuk mencuci tangan nya kembali, ditempat yang sudah disediakan oleh panitia TPS dan

9. Panitia TPS tidak lagi menyuruh pemilih untuk mencelupkan tangan nya kedalam botol tinta namun dengan sendiri nya panitia TPS akan meneteskan tinta ke tangan pemilih, kemudian pemilih diwajibkan untuk kembali kerumah masing-masing dan tidak diperkenankan untuk kumpul diarea TPS.

Demi terciptanya kesehatan dan pengendalian wabah virus Covid-19 berdasarkan wawancara penulis kepada komisioner KPU Kota Bandar Lampung yaitu Bapak Deddy Amrullah ia mengatakan bagi suatu daerah bilamana diketahui pada suatu wilayah tertentu yang tidak mempunyai fasilitas untuk melakukan pemeriksaan rapid test, bisa menggunakan surat keterangan bebas gejala seperti influenza yang dikeluarkan oleh dokter rumah sakit atau otoritas kesehatan.

Bagi pemilih yang diketahui mempunyai suhu tubuh 37,3 derajat Cellcius atau diatasnya maka petugas TPS setempat akan mempersilahkan kepada pemelih tersebut untuk menyalurkan hak suara nya di bilik khusus yang sudah dipersiapkan namun dengan mekanisme pemilihan yang sudah ditetapkan berdasarkan protokol kesehatan yaitu : 
Lintje Anna Marpaung, Baharudin, Anggalana dan Muhammad Affandi, Analisis Penyelenggaraan Pemilihan Kepala Daerah Dimasa Pandemi Covid-19 Berdasarkan Undang-Undang Nomor 6 Tahun 2020 Tentang Penetapan Peraturan Pemerintah Pengganti Undang-Undang Nomor 2 Tahun 2020 Tentang Perubahan Ketiga Atas Undang-Undang Nomor 1 Tahun 2015 Tentang Pemilihan Gubernur, Bupati, dan Walikota (Studi di KPU Kota Bandar Lampung)

1. Bagi seorang Pemilih yang ketika diperiksa suhu tubuhnya diketahui di atas 37,3 derajat cellcius maka petugas TPS setempat akan mengarahkan pemelih tersebut untuk dapat menggunakan hak suaranya di bilik khusus yang disiapkan oleh petugas.

2. Kemudian Pemilih dapat mengisi formulir model $\mathrm{C}$ yang sudah disiapkan dan daftar hadir pemilih serta menuliskan nama pendamping yang dapat dipercaya dalam hal ini petuhas KPPS pada formulir C. PendampingKWK dibantu oleh anggota KPPS.

3. Diwajibkan kepada KPPS yang mendampinggi untuk menggunakan sarung tangan plastik yang sekali pakai pada proses membantu pemilihan yang menggunakan hak suaranya di bilik khusus yang disediakan oleh panitia TPS, dengan didampingi orang yang dipercaya oleh pemilih atau dibantu oleh anggota dari KPPS.

4. Setelah mendampinggi pemilih tersebut selesai menyalurkan hak suaranya maka petugas KPPS akan meneteskan tinta pada jari pemilih tersebut. Pemilih tersebut akan dilayani di luar TPS yang dekat dengan bilik suara khusus.

5. Kemuddian pemilih diharuskan membuang sarung tangan plastik sekali pakai dan pemilih diharuskan untuk mencuci tangan pada tempat yang sudah dipersiapkan.

Dalam pemilihan dimasa pandemi Covid-19 ini hak suara yang dimiliki oleh rakyat sebagai sarana demokrasi di Daerah dengan melakukan pelaksanaan pemilihan Kepala Daerah dan Wakil Kepala Daerah Komisi Pemilihan Umum Tidak tebang pilih untuk siapa saja yang bisa memilih, untuk masyarakat yang diketahui terpapar virus korona dan diwajibkan untuk mengisolasi diri diwajibkan untuk tidak hadir atau mendatangi TPS tempat pemilih melakukan isollasi mandiri, namun petugas KPPS akan membantu pemilih dengan cara akan mendatangi ketempat atau kerumah Pemilih tersebut dengan adanya persetujuan dari saksi dan panwaslu Kelurahan/Desa atau Pengawas TPS, dengan mengedepankan asas-asas Pemilihan Umum Kepala Daerah yaitu asas rahasia yang dijamin kerahasian hak pilih dari pemilih, bagi petugas yang membantu dalam Memberikan layanan kepada Pemilih isolasi wajib melaksanakan protokol kesehatan, sedangkan mekanisme pemilihan terhadap pasien yang positif Covid-19 yang berada di rumah sakit.

1. Hal utama penyelenggara KPU Kabupaten atau Kota akan dibantu oleh Panitia Pemilihan Kecamatan atau yang disingkat PPK atau PPS, kemudian pihak rumah sakit dan anggota Gugus Tugas Covid-19 akan mendata berapa banyak pemilih yang akan mencoblos sebelum hari pemilihan.

2. setelah itu KPU Kabupaten atau Kota akan saling berkordinasi kepada pihak rumah sakit untuk dapat membentuk KPPS yang terdapat tiga orang pegawai rumah sakit.

3. kemudian sesudah KPPS yang dibentuk dari pihak rumah sakit maka penggunaan hak pilih terhadap pasien dapat dilakukan dari mulai pukul $12.00 \mathrm{WIB}$ sampai selesai.

4. kemudian diwajibkan bagi anggota yang terlibat untuk membawa perlengkapan pemungutan suara, dan mendatangi pemilih yang bersangkutan dengan menggunakan alat protokol kesehatan berupa masker, sarung tangan dan keperluan lainnya.

Sementara kepada pemilih yang diketahui sebagai yang statusnya orang dalam pantauan atau yang disingkat ODP serta pasien dalam pengawasan atau yang disingkat PDP, maka mekanisme pengunaan hak pilihnya ialah KPPS akan mendatangi mereka dengan adanya persetujuan dari saksi maupun PPL dan PPS dengan mengedepankan asas kerahasian pemilih.

Dengan demikian bahwa dapat diketahui pelaksanaan pemilukada tahun ini sangatlah berbeda dari tahun sebelumnya dikarenakan tahun ini diadakan ditengah wabah pandemi Covid-19 yang hampir menyerang seluruh dunia, meskipun terjadinya pro maupun kontra dalam pelaksanaan pemilukada tersebut namun ini bisa sebagai suatu pelajaran tersendiri bagi bangsa Indonesia bagaimana indonesia mampu untuk melaksanakan pemilihan umum Kepala Daerah meskipun di tengah pandemi Covid-19 yang memiliki prosedur rumit dan biaya yang mahal.

\section{Bagaimana dampak Pandemi Covid-19 terhadap penyelengaraan Pemilihan Kepala Daerah di kota Bandar Lampung}

Wabah Pandemi Covid-19 yang diberitakan berasal dari provinsi Cina kini berdampak diberbagai sektor kehidupan bernegara, penyebaran yang begitu cepat dan kurang nya alat kesehatan menjadikan wabah pandemi ini menimbulkan efek yang begitu besar ini bisa dilihat dengan diberlakukan nya Pembatasan Sosial Berskala Besar atau yang disingkat PSBB dan hampir diberlakukan diseluruh wilayah indonesia sehingga menimbulkan efek diberbagai sektor, seperti dalam bidang ekonomi, sosial, maupun dalam bidang ketatanegaraan.

Tahun 2020 sebagai ajang Pemilihan Umum Kepala Daerah yang digadang-gadang akan dilaksanakan pada bulan september 2020 terpaksan harus dilakukan penundaan sampai bulan Desember, penundaan pemilihan Kepala Daerah ialah salah satu dampak pandemi Covid-19 yang dialami oleh KPU, peserta Calon dan masyarakat, jika dilihat 
Lintje Anna Marpaung, Baharudin, Anggalana dan Muhammad Affandi, Analisis Penyelenggaraan Pemilihan Kepala Daerah Dimasa Pandemi Covid-19 Berdasarkan Undang-Undang Nomor 6 Tahun 2020 Tentang Penetapan Peraturan Pemerintah Pengganti Undang-Undang Nomor 2 Tahun 2020 Tentang Perubahan Ketiga Atas Undang-Undang Nomor 1 Tahun 2015 Tentang Pemilihan Gubernur, Bupati, dan Walikota (Studi di KPU Kota Bandar Lampung)

dari keputusan KPU Tahun 2020 hanya terdapat empat hal yang harus ditunda terkait jadwal pelaksanaan yaitu meliputi pelantikan panitia pemungutan suara, verifikasi syarat dukungan calon perseorangan, pembentukan Panitia Pemuktahiran Data Pemilih, serta pemuktahiran dan penyusunan daftar pemilih melihat kedalam muatan isinya tersebut, Keputusan Komisi Pemilihan Umum (KPU) tersebut hanya sebatas kepada penundaan penyelenggaraan teknis Pemilukada sampai tahap penetapan daftar pemilih.

Dampak penundaan penyelenggaraan memang sedikit memberikan efek yang positif bagi partai politik karena penundaan ini memberikan waktu yang lebih Panjang untuk berpikir kembali terkait proses perekrutan Calon Kepala Daerah Yang dianggap mampu bersaing terhadap lawan calon politik yang lain, dan juga adanya waktu kepada calon independen untuk menyiapkan persyaratan dukungan sebagai calon yang maju perseorangan, tiga bulan waktu penundaan harus digunakan benar-benar oleh partai politik atau calon yang maju perseorangan.

Berdasarkan wawancara penulis dengan ketua KPU Kota Bandar Lampung yaitu bapak Dedy Triyadi mengatakan dampak wabah pandemi Covid-19 memang merubah jadwal kegiatan penyelenggaraan yang sudah ditetapkan pada jadwal sebelumnya seperti halnya yang paling signifikan pada masa kampanye yang sebelumnya dalam PKPU tentang kampanye diperbolehkan untuk setiap calon melaksanakan kegiatan rapat umum, pertemuan terbatas, Pertemuaan tatap muka maupun kegiatan budaya dan olahraga namun dikarenakan terjadinya wabah pandemi Covid-19 KPU mengeluarkan PKPU yang mengatur tentang masa kampanye, bahwa dalam peraturan tersebut hanya terdapat 3 metode kampanye yang diperbolehkan oleh KPU bagi setiap calon yang bisa dilakukan, tentu saja hal ini untuk menghindari terjadinya penyebaran virus pandemi Covid-19 hal pertama yaitu mengenai pertemuan terbatas jumlah massa hanya dibatasi menjadi 50 orang dan dapat dilakukan didalam ruangan dengan jumlah massa tidak boleh lebih dari 50 peserta, yang ke dua terkait pertemuan tatap muka atau dialog kegiatan ini dapat dilakukan didalam gedung atau diluar Gedung tentu saja dengan mengedepankan protokol kesehatan salah satunya pembatasan maksimal Yang hadir tidak boleh lebih dari 50 orang, Kemudian yang ketiga terkait penyebaran bahan-bahan peraga kampanye seperti baliho atau famflet yang dibatasi selama 71 hari pada masa kampanye yang diberlakukan dari 26 September sampai 5 Desember, dalam masa kampanye tersebut KPU memfasilitasi yang terdiri dari pemasangan alat kampanye dan alat peraga kampanye seperti poster atau baliho sampai KPU juga memfasilitasi debat kandidat yang dimulai dari Calon walikota hingga pasanagan Calon.

Dampak lain yang timbul diakibatkan pandemi Covid-19 ialah prosedur yang lebih rumit dan biaya yang lebih mahal dari Pemilihan Umum Kepala Daerah sebelumnya ini dikarenakan setiap pemilih diwajibkan untuk menggunakan alat perlengkapan protokol kesehatan contoh berupa masker dan sarung tangan untuk dapat berpartisipasi dalam pemilihan di Tahun 2020, selain itu petugas disetiap TPS juga diwajibkan untuk mengikuti peraturan protokol kesehatan, penyebab tersebut menjadikan onkos biaya Pemilihan Kepala Daerah Tahun 2020 lebih mahal dibandingkan pemilihan Kepala Daerah sebelumnya, pembelian alat-alat seperti masker, sarung tangan, hand sanitizer dan yang terkait mengenai protokol kesehatan menyebabkan bertambahnya onkos Pemilihan Kepala Daerah, meskipun pemerintah berniat untuk dapat menghemat anggaran disemua sektor selama wabah pandemi Covid-19.

Berdasarkan wawancara penulis dengan ketua KPU kota Bandar Lampung yaitu bapak Dedy Triyadi mengatakan dampak wabah pandemi Covid-19 bukan hanya menimbulkan dampak yang negatif terhdap pemilihan Calon Kepala Daerah Namun terdapat juga dampak positif menurut Dedy Triyadi adanya kenaikan tingkat partisipasi dikalangan masyarakat sebanyak 3 persen sehingga menjadi 69,17 persen, meskipun terjadi pro dan kontra namun hal tersebut tidak mengurangi tingkat kehadiran pemilih, jumlah kenaikan pemilih tersebut tentu bukan tanpa alasan berdasarkan wawancara tersebut Dedy Triyadi mengatakan bahwa ketatnya pelaksanaan protokol kesehatan yang dilakukan oleh KPU Kota Bandar Lampung disetiap TPS menjadikan masyarakat percaya dan siap untuk dapat berpartisipasi secara langsung dalam pemilihan umum Kepala Daerah di Kota Bandar Lampung dan juga kenaikan tersebut diikuti dengan kenaikan dari para pemilih pemula yang didapati oleh KPU dalam coklit beberapa waktu lalu.

Karena dampak kenaikan tersebutlah menjadi sebab KPU Kota Bandar Lampung untuk membuat suatu terobosan terbaru dengan menggunakan aplikasi yang dibuat oleh KPU Kota Bandar Lampung ysng bernama Gelombang Demokrasi yang dapat diakses penguna smartphone android dan menjadi sarana aplikasi yang dijadikan sosialisasi oleh KPU kepada pemilih di Kota Bandar Lampung dan juga diikuti dengan adanya aplikasi E-rekap sebagai aplikasi penghitungan suara real kount dari KPU yang dapat dilihat langsung oleh masyarakat.

\section{Kampanye yang Berbeda}

Pada Pemilihan Calon Kepala Daerah di Tahun sebelumnya setiap calon akan berkampanye dengan mengumpulkan massa pada suatu titik tertentu yang sudah ditargetkan oleh Calon Kepala Daerah namun pada pemilihan Tahun 2020 ini yang diselenggarakan dalam keadaan yang berbeda karena dilaksanakan di tengah wabah Covid-19 tentu harus mengikuti aturan berdasarkan protokol kesehatan Sebagai salah satu bentuk upaya untuk tidak menimbulkan penyevaran virus Covid-19. 
Lintje Anna Marpaung, Baharudin, Anggalana dan Muhammad Affandi, Analisis Penyelenggaraan Pemilihan Kepala Daerah Dimasa Pandemi Covid-19 Berdasarkan Undang-Undang Nomor 6 Tahun 2020 Tentang Penetapan Peraturan Pemerintah Pengganti Undang-Undang Nomor 2 Tahun 2020 Tentang Perubahan Ketiga Atas Undang-Undang Nomor 1 Tahun 2015 Tentang Pemilihan Gubernur, Bupati, dan Walikota (Studi di KPU Kota Bandar Lampung)

Dalam proses pemilihan umum maupun itu pemilihan presiden ataupun pemilihan Kepala Daerah unsur kampanye bagi setiap pasangan calon sangat penting namun pada Pemilukada Tahun ini setiap calon akan dihadapi dengan bentuk kampanye yang berbeda dari sebelumnya ini dikarenakan adanya batasan-batasan tertentu yang sudah ditentukan, padahal sesungguhnya bagi calon Kepala Daerah sangat penting untuk bisa mengumpulkan massa agar mendapatkan dukungan secara langsung dikarenakan kampanye merupakan hal yang sah dalam melakukan pengumpulan massa.

Namun dengan merebaknya wabah pandemi covid-19 tentu saja akan ada sedikit perubahan khususnya di Kota Bandar Lampung bila dilihat dalam Peraturan Walikota Bandar Lampung Nomor 25 tahun 2020 kampanye yang dilakukan tentu saja harus mengikuti protokol kesahatan seperti dalam perwali tersebut ditetapkan kegiatan berkampanye hanya diberikan maksimal 3 kali yang dilaksanakan pada setiap kelurahan pada masa kampanye yang dimulai dari tanggal 26 September 2020 hingga 5 Desember 2020, batasan 3 kali berkampanye dirasakan cukup ditengah situasi yang abnormal seperti ini meskipun situasi abnormal dikarenakan pandemi Covid-19 yang menimbulkan kesulitan bagi para pihak tak terkecuali calon kepala Daerah, namun meskipun pemilukada di tengah wabah pandemi Covid-19, serta di ikuti dengan kemajuan teknologi dapat mendorong setiap calon Kepala Daerah untuk berkampanye dengan tidak mendatangkan massa yang banyak.

Namun setiap calon kepala Daerah dapat menggunakan aplikasi atau media massa seperti mengiklankan atau berkampanye dengan menjelaskan visi misi nya melalui aplikasi yang terkenal seperti facebook, instagram maupun twitter dengan bentuk kampanye seperti itu selain tidak menghamburkan uang dan juga lebih praktis dan dapat dijangkau oleh siapa pun dari kalangan milenial hingga orang tua, pengunaan teknologi yang maju sebagai pengganti metode berkampanye secara langsung dengan tidak menghadirkan massa akan digantikan dengan metode kampanye yang lebih praktis dan hemat dibandingkan tatap muka dengan menghadirkan massa dalam jumlah besar, hal positif dalam penyelenggaraan Pemilukada Tahun ini bisa dijadikan momentum oleh Calon Kepala Daerah untuk menjadikan sarana aplikasi online atau media massa sebagai sarana berkampanye, menyampaikan narasi politiknya dengan ide dan gagasan yang disampaikan melalui daring secara tenang, aman dan nyaman.

Setiap calon Kepala Daerah harus mempersiapkan diri dalam melakukan inovasi kampanye secara daring, kemungkinan kampanye melalui aplikasi online atau Media massa dapat menjadi aspirasi oleh calon kepala daerah dimasa yang akan datang untuk mengurangi kampanye dengan cara mengumpulkan massa, dari pada mengumpulkan banyak massa dan calon kepala daerah hanya bernarasi saja di atas pangung dan tidak didengar oleh sebagaian pendukung massa, namun hal Negatif nya calon kepala daerah tidak dapat mendengarkan secara langsung aspirasi masyarakat pada suatu wilayah yang dijadikan target kampanye.

Dalam hal kampanye sendiri di Kota Bandar Lampung memang sebenarnya Pmerintah Daerah tidak melarang dan membolehkan untuk mendatangkan massa kampanye di masa wabah pandemi covid-19, ini bisa dilihat dalam peraturan Walikota Bandar Lampung Nomor 25 tahun 2020 tetapi ada batasan-batasan Tertentu hanya membolehkan berkampanye dengan waktu maksimal 30 menit pada setiap titik lokasi kampanye bagi setiap peserta calon dan dalam perwali tersebut untuk massa dibatasi hanya berjumlah peserta paling banyak 50 orang dan adanya pelarangan untuk tidak melakukan tatap muka dari rumah ke rumah dalam kampanye.

Kampanye dengan menghadirkan massa tentu sudah diketahui sejak lama sebagai ajang kampanye politik transaksional saja yang membagi-bagikan uang kepada massa bentuk sebagai politik imbalan atau timbal balik serta jauh dari ide dan gagasan yang akan disampaikan oleh calon Kepala Daerah, diharapkan pemilihan Tahun 2020 dimasa pandemi Covid-19 ini dapat mengubah metode gaya baru dalam cara berkampanye bagi para kandidat dimasa yang akan datang karena dinilai lebih efektif dan terjangkau kepada masyarakat serta tanpa disadari akan membuat anak-anak milenial menjadi lebih tertarik untuk mengikuti pemilihan umum dibandingkan hanya orasi disuatu tempat, dan disinilah tim pemenangan calon akan dituntut lebih inovatif dan kreatif dalam melakukan kampanye melalui media sosial.

\section{SIMPULAN}

1. Mekanisme pemilihan Kepala Daerah di Tahun 2020 yaitu dimulai dari masyarakat yang memiliki suhu normal wajib menggunakan masker, melakukan cuci tangan yang sudah disiapkan oleh TPS setempat dengan menggunakan Hand Sanitizer, menggunakan sarung tangan sekali pakai, dicek suhu tubuh nya dengan menggunakan Thermo Gun, menunggu giliran dengan menerapkan physical distancing, dipangil oleh petugas TPS, Setelah melakukan pemberian suara maka pemilih diwajibkan untuk membuang sarung tangan plastik yang diberikan oleh petugas TPS pemilih dipersilakan untuk mencuci tangan nya kembali ditempat yang sudah disediakan setelah itu petugas akan meneteskan tinta ke tangan pemilih, kemudian pemilih diwajibkan untuk kembali kerumah masing-masing dan tidak diperkenankan untuk kumpul diarea TPS, kemudian untuk pemilih yang memiliki suhu 37,3 derajat celcius pemilih memiliki bilik khusus yang diarahkan oleh petugas, kemudian 
Lintje Anna Marpaung, Baharudin, Anggalana dan Muhammad Affandi, Analisis Penyelenggaraan Pemilihan Kepala Daerah Dimasa Pandemi Covid-19 Berdasarkan Undang-Undang Nomor 6 Tahun 2020 Tentang Penetapan Peraturan Pemerintah Pengganti Undang-Undang Nomor 2 Tahun 2020 Tentang Perubahan Ketiga Atas Undang-Undang Nomor 1 Tahun 2015 Tentang Pemilihan Gubernur, Bupati, dan Walikota (Studi di KPU Kota Bandar Lampung)

Pemilih dapat mengisi formulir sudah disiapkan dan daftar hadir pemilih, KPPS akan mendampinggi untuk menggunakan sarung tangan plastik sekali pakai pada proses membantu pemilihan, setelah pemilih selesai menyalurkan hak suaranya maka petugas KPPS akan meneteskan tinta pada jari pemilih tersebut. Kemudian pemilih diharuskan membuang sarung tangan plastik sekali pakai dan pemilih diharuskan untuk mencuci tangan pada tempat yang sudah dipersiapkan dan kembali, untuk pemilih yang terpapar virus Covid-19 atau pemilih yang melakukan rawat inap pemilih tersebut akan dilayani dengan cara petugas KPPS didampingi saksi akan menuju di mana pemilih tersebut melakukan isolasi atau rawat inap.

2. Dampak Positif yang dialami oleh KPU Kota Bandar Lampung ialah terjadinya jumlah kenaikan pemilih yaitu berjumlah tiga persen kenaikan ini yang menjadikan KPU Kota Bandara Lampung membuat suatu aplikasi sebagai sarana sosialisai kepada masyarakat untuk dapat mengakses informasi secara cepat dan transparan kepada masyarakat selain itu dampak positif bagi calon partai politik ialah untuk bisa berpikir kembali untuk merekrut calon Kepala Daerah yang diangap mampu untuk bersaing dan memajukan Kota Bandar Lampung kemudian kepada calon independen dapat menyiapkan persyaratan dukungan sebagai calon yang maju perseorangan dengan jangka waktu yang lebih lama.

Dampak Negatif dilakukan penundaan Pemilukada sampai bulan Desember, yang sebelumnya bulan September selain itu ditunda jadwal pelaksanaan meliputi pelantikan panitia pemungutan suara, verifikasi syarat dukungan calon perseorangan, pembentukan Panitia Pemuktahiran Data Pemilih, serta pemuktahiran dan penyusunan daftar pemilih dan prosedur pelaksanaan lebih rumit yang dialami oleh pemilih karena diwajibkan untuk melakukan prosedur sesuai protol kesehatan dan biaya yang lebih mahal dari Pemilihan Kepala Daerah sebelumnya karena pengunaan alat protokol kesehatan menjadi biaya tambahan dalam pelaksanaan pemilihan Kepala Daerah.

\section{DAFTAR PUSTAKA}

\section{Buku}

Hendra Budiman, Pilkada Tidak Langsung dan Demokrasi Palsu. Pustaka Yustisia, Yogyakarta, 2015.

Lintje Anna Marpaung, Revitalisasi Hukum Otonomi Daerah Prospektif Kepentingan Daerah, Aura, Bandar Lampung, 2016.

\section{Jurnal}

Farahdiba Rahma Bactiar. 2014. Pemilu Indonesia: Kiblat Negara Demokrasi dari Berbagai Representasi. dimuat pada Jurnal Politik Profetik, Vol. 3, No. 1, 2014

Janpatar Simamora. 2011. Eksistensi Pemilukada Dalam Rangka Mewujudkan Pemerintahan Daerah yang Demokratis. Volume 23, Nomor 1, Februari 2011 